\title{
Current and future concepts in stroke prevention
}

\author{
Fintan O'Rourke, Naeem Dean, Naveed Akhtar, Ashfaq Shuaib
}

ß See related articles pages 1099, 1105, 1113 and 1134

Abstract

STROKE IS A MAJOR CAUSE OF MORBIDITY and mortality in an aging population. The current understanding of the pathophysiology of atherosclerotic diseases, the most common cause of stroke, and the evidence for existing therapeutic interventions for the prevention of stroke are presented. Specifically, we review the evidence for antiplatelet agents, anticoagulants, antihypertensive medications, lipidlowering agents and carotid endarterectomy for stroke prevention.

CMAJ 2004;170(7):1123-33

$\mathrm{E}$ ach year in Canada stroke occurs in 50000 people and accounts for $7 \%$ of all deaths. Canada's population of stroke survivors numbers almost 300000 , of whom $30 \%$ remain permanently disabled..$^{1-3}$ Care for stroke patients accounts for $2.1 \%$ of Canadian health care expenditures. ${ }^{4}$ Primary prevention of a first stroke and secondary prevention of recurrent events require rapid identification of risk factors and implementation of appropriate preventive measures.

The risk of stroke following an initial cerebrovascular event is high. Of patients presenting to an emergency department with a transient ischemic attack (TIA), $10.5 \%$ will have a stroke (half of these occurring in the first 2 days) and 2.6\% will die within 90 days. ${ }^{5}$ Overall, $8.8 \%$ of stroke survivors will have a recurrent stroke within the first 6 months, and $15 \%$ within 5 years. ${ }^{6}$ In most cases (about $50 \%$ ) the stroke is atherothrombotic in origin, with a further $25 \%$ attributable to small-vessel lacunar disease and $20 \%$ to cardioembolism. Data from a stroke registry reveal that patients who have an atherothrombotic stroke have the highest rates of recurrence within 30 days (18.5\%), as compared with those who have a lacunar $(1.4 \%)$ or cardioembolic $(5.3 \%)$ stroke. ${ }^{7}$

In this review we present the current understanding of the pathophysiology of atherosclerotic disease, the most common cause of stroke. We also provide an overview of the available evidence for common therapeutic interventions used for stroke prevention: antiplatelet agents, anticoagulants, antihypertensive medications, lipid-lowering agents and carotid endarterectomy.

\section{Atherogenesis}

Atherosclerotic plaques begin to appear in the second and third decade of life. It is now widely agreed that inflammation at an endothelial level is the trigger for atherosclerosis. ${ }^{8}$ Leukocytes (predominantly monocytes and T-lymphocytes) localize in the earliest atherosclerotic lesions. They bind to vascular cell adhesion molecules (VCAM-1) on the vascular endothelium and migrate into the intima., ${ }^{910}$ This initiates and perpetuates a local inflammatory response. The monocytes mature into lipid-scavenging macrophages and subsequently foam cells. T-lymphocytes express inflammatory cytokines, which continue to stimulate macrophages and endothelial cells and further proliferation of smooth muscle cells ${ }^{11}$ (Fig. 1).

Sites that experience disturbed blood flow and increased wall stresses, such as arterial branch points, seem to be at highest risk of atherosclerosis and demonstrate impaired atheroprotective mechanisms. ${ }^{12}$ Nitric oxide production, which inhibits platelet aggregation, proliferation of arterial smooth muscle cells and expression of VCAM-1, may be reduced in these sites. ${ }^{13}$ Furthermore, smooth muscle cells at these sites produce increased proteoglycans that promote inflammation by facilitating the oxidation of lipoproteins. ${ }^{14}$

Acute rupture of atherosclerotic plaques, rather than gradual encroachment of the plaque causing luminal narrowing, is the main cause of vascular morbidity and mortality. Both immunologic and mechanical forces are thought to be responsible for plaque rupture, which then precipitates thrombosis. Macrophages produce proteolytic enzymes that degrade the collagen of the plaque's fibrous cap, which makes it susceptible to rupture,,$^{15}$ and produce procoagulant tissue factor, which triggers plaque thrombosis. ${ }^{16}$

An elevated C-reactive protein level, a marker of inflammation, inhibits nitric oxide release and thus promotes monocyte activation and adhesion to endothelium and increases low-density lipoprotein (LDL) uptake into existing plaques. ${ }^{17-19}$ It is associated with an increased risk of coronary and cerebrovascular events, independent of other known risk factors for vascular disease. ${ }^{20}$ Stroke risk in the highest quartile of C-reactive protein levels is almost double among men and threefold among women as compared with the lowest quartile. ${ }^{21}$ Therefore, it is hoped that interventions that reduce C-reactive protein levels may also reduce endothelial inflammation and vascular risk. ASA, for example, appears to offer its greatest protective effect in patients in the highest quartile of C-reactive protein levels, reducing the risk of myocardial infarction in this group of men by $55.7 \%$ compared with a nonsignificant $13.9 \%$ in the lowest quartile of $\mathrm{C}$-reactive protein levels. ${ }^{22}$

\section{Antiplatelet agents}

ASA irreversibly blocks platelet cyclooxygenase and thus prevents the formation of thromboxane $\mathrm{A}_{2}$ (Fig. 2). As a 
primary preventive measure, antiplatelet agents do not reduce the risk of ischemic stroke among patients without vascular disease. They are associated with an increased risk of intracranial hemorrhage (odds ratio [OR] 1.35, 95\% confidence interval [CI] $0.88-2.10)^{23}$ and major noncerebral hemorrhage (OR 1.73, 95\% CI 1.14-2.63)..24

The benefits of ASA in the secondary prevention of

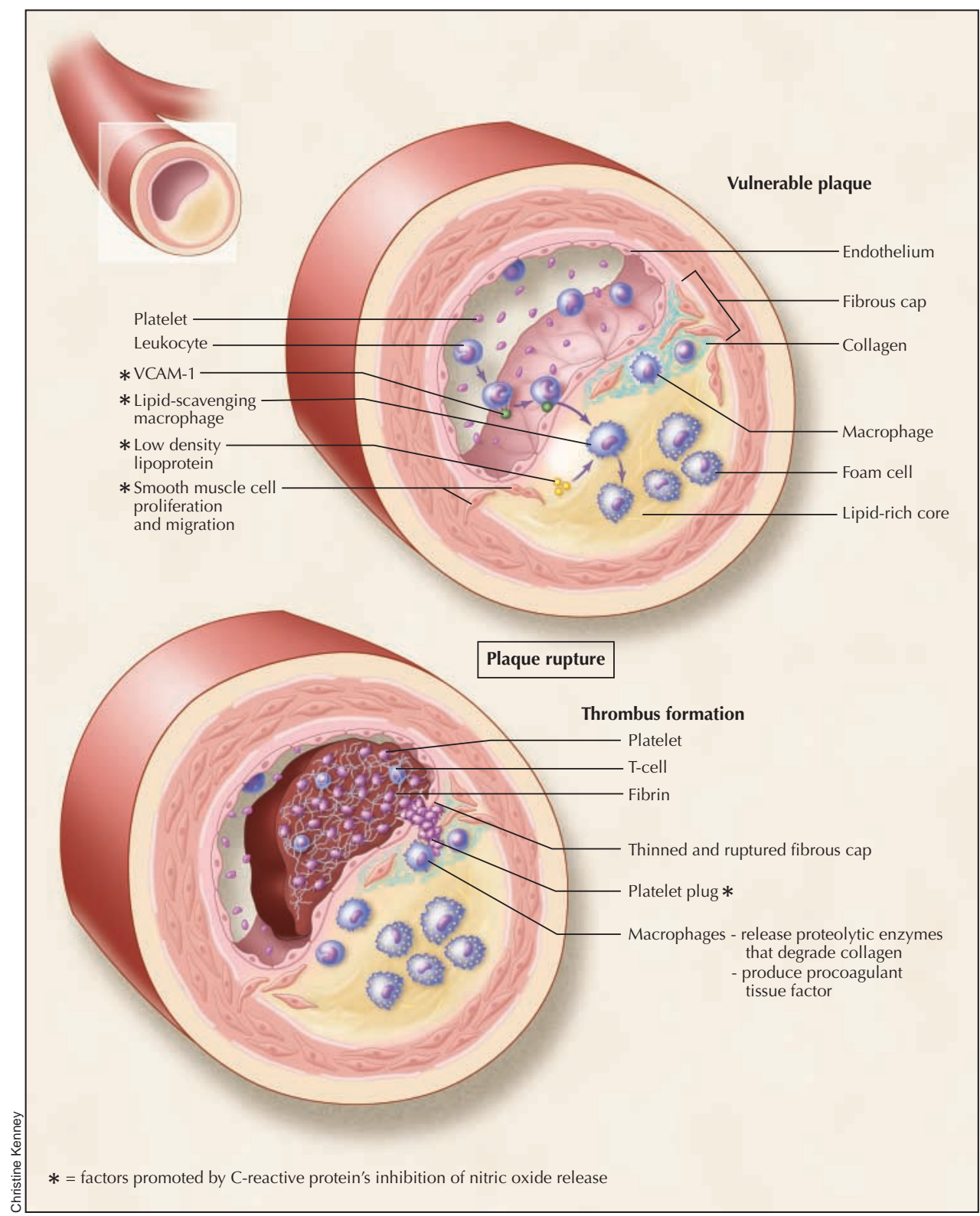

Fig. 1: The role of inflammatory processes in thrombus formation and plaque rupture. Leukocytes localize in the earliest atherosclerotic lesions, binding to vascular cell adhesion molecules (VCAM-1) on the vascular endothelium and migrating into the intima. This initiates and perpetuates a local inflammatory response. Monocytes mature into lipid-scavenging macrophages and subsequently foam cells. T-lymphocytes express inflammatory cytokines, which continue to stimulate macrophages and endothelial cells and further proliferation of smooth muscle cells. Later, macrophages produce proteolytic enzymes that degrade the collagen of the plaque's fibrous cap, making it susceptible to rupture, and produce procoagulant tissue factor, which triggers plaque thrombosis. stroke have been well documented in the period immediately after a stroke ${ }^{25}$ (Table 1). Long-term antiplatelet treatment after stroke shows an even more impressive reduction of 25 nonfatal strokes and 36 serious vascular events per 1000 treated over a 29-month follow-up period. ${ }^{25}$ There appears to be no difference in efficacy between low $(50 \mathrm{mg})$ and higher doses (up to $1500 \mathrm{mg}$ ) of ASA. ${ }^{29,30}$

The combination of dipyridamole and ASA has been shown to reduce the relative risk of recurrent stroke compared with ASA alone ${ }^{26}$ (Table 1). Dipyridamole inhibits platelet aggregation by increasing levels of cyclic adenosine monophosphate and cyclic guanosine monophosphate. The limiting factor in the use of the ASAdipyridamole combination is the latter's potential effects on coronary perfusion. Dipyridamole can cause coronary vasodilation, which results in increased blood flow to nonstenosed coronary arteries. The result is that myocardial ischemia may be provoked during exercise. As such, the current American College of Cardiology/American Heart Association guidelines recommend that dipyridamole not be used in patients with chronic stable angina. ${ }^{31}$ However, this recommendation was based on shortacting dipyridamole, which also reduced myocardial ischemia in a similar number of patients in the study quoted by these guidelines. ${ }^{32}$ With the use of sustained-release dipyridamole, no increase in cardiac events was observed in subjects with prior coronary artery disease. ${ }^{33}$

Thienopyridines block adenosine-diphosphate-mediated platelet aggregation. Ticlopidine was the first of this class of drug to be studied for stroke prevention. One clinical trial demonstrated that patients treated with ticlopidine had similar rates of stroke as those treated with $\mathrm{ASA}^{28}$ (Table 1). However, serious granulocytopenia associated with ticlo- 
pidine has limited its use. Clopidogrel is a secondgeneration thienopyridine that has also shown similar efficacy to ASA in stroke prevention ${ }^{27}$ (Table 1), without any increased risk of major hemorrhage or granulocytopenia. Among patients with acute coronary syndromes, vascular events occurred in $9.3 \%$ of those given clopido-

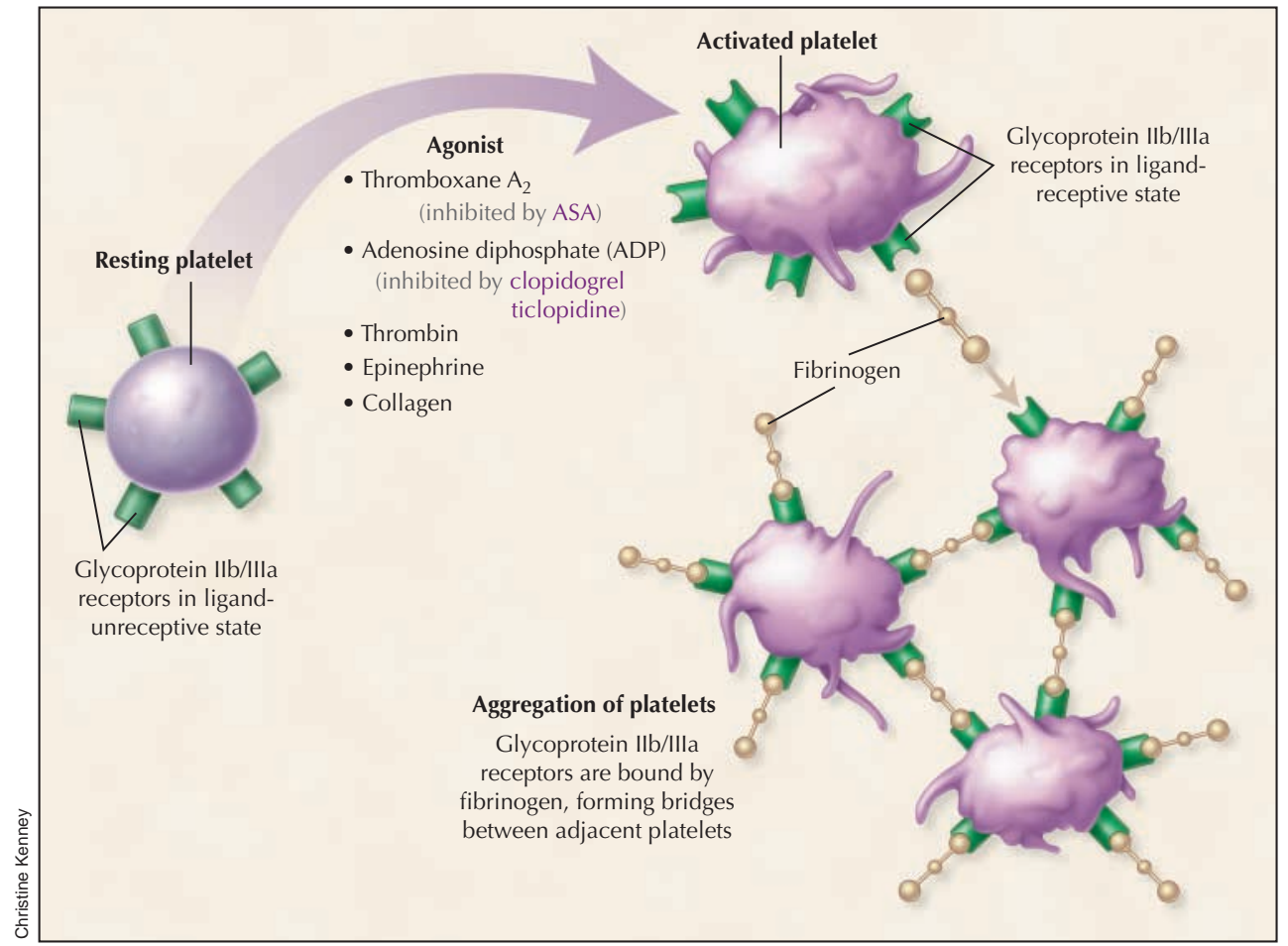

Fig. 2: Platelet aggregation and subsequent thrombosis may be prevented by several mechanisms and agents. ASA blocks platelet cyclooxygenase and the formation of thromboxane $\mathrm{A}_{2}$, while the thienopyridines block adenosine-diphosphate-mediated aggregation.

\section{Table 1: Major trials of antiplatelet agents}

\begin{tabular}{|c|c|c|c|c|c|c|c|}
\hline Trial & Patients & Follow-up & Intervention & Absolute risk, \% & OR $(95 \% \mathrm{Cl})$ & Superior & Comments \\
\hline $\begin{array}{l}\text { IST/CAST } \\
\text { Combined } \\
\text { analysis }^{25} \\
n=40000\end{array}$ & $\begin{array}{l}\text { Acute stroke } \\
\text { in previous } \\
48 \mathrm{~h}\end{array}$ & $\begin{array}{l}\text { CAST } 28 \mathrm{~d} ; \\
\text { IST } 14 \mathrm{~d}\end{array}$ & $\begin{array}{c}\text { ASA } \\
\text { v. placebo }\end{array}$ & $\begin{array}{c}\text { Recurrent IS } \\
1.6 \\
2.3 \\
\text { Death } \\
6.1 \\
6.5\end{array}$ & $0.70(0.61-0.80)$ & ASA & $\begin{array}{c}\text { NNT 7/1000 (CAST); } \\
\text { NNT 4/1000 }\end{array}$ \\
\hline $\begin{array}{l}\text { ESPS- } 2^{26} \\
n=6602\end{array}$ & $\begin{array}{l}\text { Stroke or TIA } \\
\text { in previous } \\
3 \text { mo }\end{array}$ & $2 \mathrm{yr}$ & $\begin{array}{c}\text { ASA } \\
\text { v. DP } \\
\text { v. ASA + DP } \\
\text { v. placebo }\end{array}$ & $\begin{array}{c}\text { Stroke risk } \\
12.9 \\
13.2 \\
9.9 \\
15.8\end{array}$ & $\begin{array}{c}\text { v. placebo } \\
0.79(0.65-0.97) \\
0.81(0.67-0.99) \\
0.59(0.48-0.73) \\
-\end{array}$ & $\mathrm{ASA}+\mathrm{DP}$ & $\begin{array}{l}\text { Avoid DP in patients } \\
\text { with chronic stable } \\
\text { angina }\end{array}$ \\
\hline $\begin{array}{l}\text { CAPRIE }^{27} \\
n=19185\end{array}$ & $\begin{array}{l}\text { Prior } \mathrm{MI} \text {, stroke } \\
\text { or peripheral } \\
\text { arterial disease }\end{array}$ & $1.91 \mathrm{yr}$ & $\begin{array}{l}\text { Clopidogrel } \\
\text { v. ASA }\end{array}$ & $\begin{array}{l}\text { Composite of IS, MI, } \\
\text { vascular death } \\
5.3 \\
5.8\end{array}$ & $0.91(0.83-0.96)$ & Clopidogrel & $\begin{array}{l}\text { No difference in } \\
\text { efficacy for stroke } \\
\text { prevention; no major } \\
\text { safety differences }\end{array}$ \\
\hline $\begin{array}{l}\mathrm{TASS}^{28} \\
n=927\end{array}$ & $\begin{array}{l}\text { Minor stroke in } \\
\text { previous } 3 \mathrm{mo}\end{array}$ & $2-6 y r$ & $\begin{array}{l}\text { Ticlopidine } \\
\text { v. ASA }\end{array}$ & $\begin{array}{c}\text { All strokes } \\
14.2 \\
16.0 \\
\text { Nonfatal stroke } \\
\text { or death } \\
20.8 \\
24.8\end{array}$ & $\begin{array}{l}0.88(0.61-1.26) \\
0.79(0.58-1.08)\end{array}$ & $\begin{array}{c}\text { No } \\
\text { difference }\end{array}$ & $\begin{array}{l}\text { Ticlopidine rarely } \\
\text { used because of safety } \\
\text { concerns }(2.6 \% \text { rate } \\
\text { of neutropenia in } \\
\text { study) }\end{array}$ \\
\hline
\end{tabular}

Note: When not provided in the study, unadjusted odds ratios (ORs) and $95 \%$ confidence intervals $(\mathrm{Cls})$ were calculated. ASA $=$ acetylsalicylic acid, IS $=$ ischemic stroke, NNT = number needed to treat, $\mathrm{TIA}=$ transient ischemic attack, $\mathrm{DP}=$ dipyridamole, $\mathrm{MI}=$ myocardial infarction. 
grel and ASA, as compared with $11.4 \%$ of those given placebo and ASA. ${ }^{34}$ Although there were significantly more patients with major hemorrhage in the clopidogrel group than in the placebo group (3.7\% v. $2.7 \%)$, there were not significantly more patients with life-threatening or intracranial hemorrhage. To date, there are no published studies specifically examining the ASA-clopidogrel combination in stroke prevention, although several are ongoing.

\section{Summary}

ASA remains a first-line therapy in the secondary prevention of atherothrombotic stroke after a first episode, although combination therapy with ASA and dipyridamole is also justified in the absence of coronary artery disease. Clopidogrel is recommended if the patient is ASAintolerant. Patients with recurrent TIA or stroke while taking ASA should be re-evaluated to exclude other pathogeneses. If none is found, ASA-dipyridamole combination therapy should be given if not already prescribed. Further events, intolerance to dipyridamole or the presence of coexisting coronary or peripheral vascular disease should merit consideration of an ASA-clopidogrel combination therapy.

\section{Anticoagulants}

Anticoagulation is achieved primarily with heparin and warfarin. Unfractionated heparin binds with antithrombin III and thus accelerates its neutralizing effects on thrombin and inactivates clotting factors. Warfarin, a vitamin $\mathrm{K}$ antagonist, prevents the vitamin $\mathrm{K}$-dependent activation of clotting factors II, VII, IX and X.

There is no evidence supporting anticoagulation in the treatment of acute stroke. Although heparin decreases the incidence of recurrent ischemic stroke in the short term, the benefits are offset by increases in the rates of hemorrhagic stroke ${ }^{35-37}$ (Table 2). The remainder of this section examines the role of warfarin in modifying various clinical risk factors for the long-term prevention of stroke.

\section{Atrial fibrillation}

As previously mentioned, ischemic stroke is due to cardioembolism in about $20 \%$ of cases. Of these, the majority occur because of a mural thrombus in patients with atrial fibrillation. The annual rate of stroke with atrial fibrillation is about $4.5 \%$. The risk of stroke is increased among patients who have hypertension, diabetes mellitus, left ventricular dysfunction, prior TIA or stroke and are older than 65 . Anticoagulation reduces the annual risk to $1.4 \%$. Patients younger than 65 with atrial fibrillation and no other risk factors had only a $1 \%$ rate of stroke, even without treatment..$^{42}$ Long-term treatment with warfarin to achieve an international normalized ratio (INR) above 2.0 decreases not only the risk of stroke, but also its clinical sever- ity and the risk of death. ${ }^{43}$ ASA has also been shown to be more effective than placebo in this group of patients but less effective than warfarin ${ }^{38}$ (Table 2).

The risk of hemorrhagic complications is often a concern when considering long-term anticoagulation for atrial fibrillation. However, one study ${ }^{39}$ demonstrated that the annual risk of ischemic stroke or systemic embolism was greater among patients assigned to low-intensity anticoagulation combined with ASA than among those given full anticoagulation $(7.9 \%$ v. $1.9 \%)$, with no difference in major bleeding (Table 2).

Until recently, conversion of atrial fibrillation to sinus rhythm with the use of electrical or pharmacological methods was felt to be beneficial in reducing long-term embolic complications. However, 2 studies have challenged this concept, showing no significant difference in mortality or stroke reduction between a strategy of restoring and maintaining sinus rhythm and another aimed at rate control of chronic atrial fibrillation. Most strokes occurred only when anticoagulation was stopped or was subtherapeutic. ${ }^{4,45}$

\section{Other causes of cardioembolic stroke}

Patients with mechanical prosthetic heart valves are at high risk of stroke from thromboembolism and require anticoagulation at a level determined by the type of valve. If systemic embolism occurs despite adequate anticoagulation with a target INR of 3.0, 80-100 mg of ASA should be added. Patients with bioprosthetic valves require anticoagulation only for the first 3 months after valve insertion. Thereafter, ASA alone is sufficient prophylaxis. ${ }^{46}$

Despite treatment with thrombolytic agents, left ventricular thrombus may occur in $28 \%$ of patients who have an acute anterior myocardial infarction, with even higher rates in the presence of apical hypokinesis. ${ }^{47,48}$ The high risk of subsequent embolic events (OR 5.45, 95\% CI 3.02-9.83) may be significantly reduced with anticoagulation (OR $0.14,95 \%$ CI $0.04-0.52)^{49}$ and has been suggested for $1-3$ months after anterior myocardial infarction ${ }^{50}$ especially when complicated by severe left ventricle dysfunction or previous emboli.

The presence of aortic atheroma of $4 \mathrm{~mm}$ or more in thickness causes a 3- to 9-fold increased risk of stroke. ${ }^{51-53}$ This risk is further increased if the atheroma is mobile ${ }^{53,54}$ or noncalcified. ${ }^{52}$ The limited evidence available ${ }^{53,54}$ suggests that anticoagulation is superior to antiplatelet treatment in preventing a combined end-point of embolic events and death for atheroma that are $4 \mathrm{~mm}$ or more in thickness or are mobile.

The presence of patent foramen ovale (PFO) may increase the risk of ischemic stroke via paradoxical embolism through right-to-left shunting. PFO is found at autopsy in $26 \%$ of the general population and $46 \%$ of patients with cryptogenic stroke under the age of $55 . .^{55} \mathrm{~A}$ meta-analysis of treatments showed that anticoagulation was superior to antiplatelet therapy for secondary stroke 
prevention in the presence of PFO (OR 0.37, 95\% CI $0.23-0.60)$ and that surgical $\mathrm{PFO}$ closure was comparable to anticoagulation (OR 1.19, 95\% CI 0.62-2.27). ${ }^{56}$ Definitive percutaneous transcatheter closure of $\mathrm{PFO}$ has been shown to be successful in preventing neurologic events in previously symptomatic patients, in addition to being safe and minimally invasive. ${ }^{57}$ However, a recent study found no difference in 2-year recurrent event rates (stroke or TIA, death) between those with or without PFO and atrial septal aneurysm, ${ }^{58}$ which raises the question of

\section{Table 2: Major trials of anticoagulants}

\begin{tabular}{|c|c|c|c|c|c|c|c|}
\hline Trial & Patients & Follow-up & Intervention & Absolute risk & OR $(95 \% \mathrm{Cl})$ & Superior & Comments \\
\hline $\begin{array}{l}\mathrm{IST}^{35} \\
n=19435\end{array}$ & $\begin{array}{l}\text { Acute stroke } \\
\text { in previous } \\
48 \mathrm{~h}\end{array}$ & $14 \mathrm{~d}$ & $\begin{array}{c}\text { Heparin } \\
\text { v. no heparin }\end{array}$ & $\begin{array}{c}\text { IS, \% } \\
2.9 \\
3.8 \\
\text { Death or nonfatal } \\
\text { stroke, \% } \\
11.7 \\
12.0\end{array}$ & 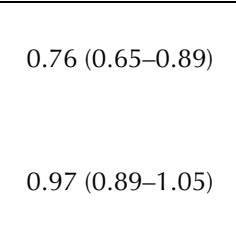 & No heparin & $\begin{array}{l}\text { Decrease in recurrent } \\
\text { IS in heparin group } \\
\text { offset by increased } \\
\text { risk of } \mathrm{HS}(\mathrm{OR} 2.95 \text {, } \\
95 \% \mathrm{Cl} 2.07-4.21)\end{array}$ \\
\hline $\begin{array}{l}\text { IST } \\
\text { subgroup }^{36} \\
n=3169\end{array}$ & $\begin{array}{l}\text { Acute stroke } \\
\text { in previous } \\
48 \mathrm{~h}+\mathrm{AF}\end{array}$ & $\begin{array}{l}14 \mathrm{~d} \text { (no effect } \\
\text { on death/ } \\
\text { dependency } \\
\text { at } 6 \text { mo } \\
\text { follow-up }\end{array}$ & $\begin{array}{l}\text { High-dose heparin } \\
\text { v. low-dose heparin } \\
\text { v. no heparin } \\
\text { (half of patients in } \\
\text { each group received } \\
\text { ASA } 300 \mathrm{mg} \text { ) }\end{array}$ & $\begin{array}{c}\text { IS, } \% \\
2.3 \\
3.4 \\
4.9 \\
\text { Death or nonfatal } \\
\text { stroke, \% } \\
18.8 \\
19.4 \\
20.7\end{array}$ & $\begin{array}{l}\text { Heparin v. none } \\
0.56(0.39-0.82)\end{array}$ & No heparin & $\begin{array}{l}\text { Decrease in recurrent } \\
\text { IS in heparin group } \\
\text { offset by increased } \\
\text { risk of HS (OR } 4.81 \text {, } \\
95 \% \mathrm{Cl} 2.12-10.9)\end{array}$ \\
\hline $\begin{array}{l}\text { TAIST }^{37} \\
n=1486\end{array}$ & $\begin{array}{l}\text { Acute stroke } \\
\text { in previous } \\
48 \mathrm{~h}\end{array}$ & $\begin{array}{l}10 \mathrm{~d} \text { (no } \\
\text { difference } \\
\text { in } 6 \text { mo } \\
\text { independence } \\
\text { between } \\
\text { groups) }\end{array}$ & $\begin{array}{c}\text { High-dose tinzaparin } \\
\text { v. low-dose tinzaparin } \\
\text { v. ASA }\end{array}$ & $\begin{array}{l}\text { Stroke, \% } \\
3.3 \\
4.7 \\
3.1 \\
\text { Death, \% } \\
3.5 \\
5.5 \\
3.5\end{array}$ & $\begin{array}{c}\text { High- and low-dose } \\
\text { tinzaparin v. ASA } \\
1.08(0.53-2.21) \\
1.58(0.82-3.04) \\
1.07(0.55-2.11) \\
1.63(0.88-3.02)\end{array}$ & $\begin{array}{l}\text { No } \\
\text { difference } \\
\text { in main } \\
\text { outcome } \\
\text { measures }\end{array}$ & $\begin{array}{l}\text { Large increase in } \\
\text { early SICH with } \\
\text { tinzaparin treatment } \\
\text { (OR for high-dose } \\
\text { tinzaparin } 7.15,95 \% \\
\mathrm{Cl} 1.10-163 \text { ) }\end{array}$ \\
\hline $\begin{array}{l}\mathrm{EAFT}^{38} \\
n=1007\end{array}$ & $\begin{array}{l}\mathrm{AF}+\text { recent } \\
\mathrm{TIA} \text { or stroke }\end{array}$ & $2.3 \mathrm{yr}$ & $\begin{array}{c}\text { AC } \\
\text { v. ASA } \\
\text { v. placebo }\end{array}$ & $\begin{array}{c}\text { Stroke risk, \% } \\
4 \\
10 \\
12 \\
\text { Major and fatal } \\
\text { bleeding, \% } \\
2.8 \\
0.9 \\
0.7\end{array}$ & $\begin{array}{c}\text { AC v. ASA } \\
0.38(0.23-0.64)\end{array}$ & $\mathrm{AC}$ & $\begin{array}{l}\text { Clear benefit of AC } \\
\text { over ASA in } \\
\text { preventing recurrent } \\
\text { stroke secondary } \\
\text { to AF; significant } \\
\text { increase in bleeding } \\
\text { events for AC } \\
\text { compared to ASA } \\
\text { (HR 2.8, Cl 1.7-4.8) } \\
\text { and placebo (HR 3.4, } \\
\mathrm{Cl} 1.9-6.0)\end{array}$ \\
\hline $\begin{array}{l}\text { SPAF-III }{ }^{39} \\
n=1044\end{array}$ & $\begin{array}{l}\mathrm{AF}+1 \\
\text { thrombo- } \\
\text { embolic risk } \\
\text { factor }\end{array}$ & $\begin{array}{c}1.1 \mathrm{yr} \text { (stopped } \\
\text { early) }\end{array}$ & $\begin{array}{c}\text { AC }(\text { INR 2-3) } \\
\text { v. AC }(\text { INR 1.2-1.5) } \\
+ \text { ASA }\end{array}$ & $\begin{array}{c}\text { Stroke or systemic } \\
\text { embolism per yr } \\
1.9 \\
7.9 \\
\text { Disabling stroke per yr } \\
1.7 \\
5.6\end{array}$ & $0.23(0.11-0.46)$ & $\begin{array}{c}\text { AC } \\
(\text { INR 2-3) }\end{array}$ & $\begin{array}{l}\text { Rates of major } \\
\text { bleeding similar in } \\
\text { both groups }(2.4 \% \\
\text { and } 2.1 \%)\end{array}$ \\
\hline $\begin{array}{l}\mathrm{SPIRIT}^{40} \\
n=1316\end{array}$ & $\begin{array}{l}\text { TIA or IS of } \\
\text { noncardiac } \\
\text { origin in } \\
\text { previous } \\
6 \text { mo }\end{array}$ & $14 \mathrm{mo}$ & $\begin{array}{c}\mathrm{AC}(\mathrm{INR} 3.0-4.5) \\
\text { v. ASA } 30 \mathrm{mg}\end{array}$ & $\begin{array}{c}\text { Composite of death, } \\
\text { stroke, MI, major } \\
\text { bleeding, \% } \\
12.4 \\
5.4\end{array}$ & HR 2.3 (1.6-3.5) & ASA & $\begin{array}{l}\text { No benefit for } \\
\text { high-intensity AC } \\
\text { over ASA in } \\
\text { noncardioembolic } \\
\text { stroke }\end{array}$ \\
\hline $\begin{array}{l}\text { WARSS }^{41} \\
n=2206\end{array}$ & $\begin{array}{l}\text { IS of } \\
\text { noncardiac } \\
\text { origin in } \\
\text { previous } 30 \mathrm{~d}\end{array}$ & $2 y r$ & $\begin{array}{c}\text { AC (INR 1.4-2.8) } \\
\text { v. ASA } 325 \mathrm{mg}\end{array}$ & $\begin{array}{c}\text { IS or death, \% } \\
17.8 \\
16.0 \\
\text { Major bleeding } \\
\text { per 100 patient-yr } \\
2.2 \\
1.5\end{array}$ & $1.48(0.93-2.44)$ & $\begin{array}{c}\text { No } \\
\text { difference }\end{array}$ & $\begin{array}{l}\text { No benefit for low- } \\
\text { to mid-intensity AC } \\
\text { over ASA in } \\
\text { noncardioembolic } \\
\text { stroke }\end{array}$ \\
\hline
\end{tabular}

Note: When not provided in the study, unadjusted $\mathrm{ORs}$ and $95 \% \mathrm{Cls}$ were calculated. $\mathrm{HS}=$ hemorrhagic stroke, $\mathrm{AF}=$ atrial fibrillation, $\mathrm{SICH}=$ symptomatic intracranial hemorrhage, $\mathrm{AC}=$ anticoagulation, $\mathrm{INR}=$ international normalized ratio, $\mathrm{HR}=$ hazard ratio, $\mathrm{DM}=$ diabetes mellitus, $\mathrm{LVH}=$ left ventricular hypertrophy. 
whether aggressive anticoagulation or surgical treatment is truly warranted.

\section{Recurrent stroke of noncardioembolic origin}

Anticoagulation may seem an attractive option for patients with recurrent cerebrovascular ischemia without an identifiable cardiac source in whom antiplatelet options have been exhausted. However, one study demonstrated no difference between ASA and warfarin (target INR 1.4-2.8) in reducing the risk of recurrent noncardioembolic stroke ${ }^{41}$ (Table 2). A similar study also found that anticoagulation (target INR 3.0-4.5) was associated with an increased risk of overall bleeding compared with ASA (OR $1.43,95 \%$ CI $0.96-2.13$ for each 0.5 unit increase in INR) largely attributable to an increase in intracranial hemorrhage ${ }^{40}$ (Table 2).

The presence of antiphospholipid antibody is an independent risk factor for first ischemic stroke, occurring in $9.7 \%$ of stroke patients versus $4.3 \%$ of control subjects in one study (adjusted OR 2.31). ${ }^{59}$ Although ASA is sufficient prophylaxis as primary prevention, ${ }^{60}$ for patients who have had a previous thrombotic event, anticoagulation greatly reduces the risk of recurrent events, both venous and arterial (hazard ratio [HR] 0.32, 95\% CI $0.15-$ 0.7 for INR < 3) as compared with ASA (HR 0.93, 95\% CI $0.51-1.68) .{ }^{61}$

\section{Summary}

Heparin should be avoided in the treatment of acute stroke. Treatment with warfarin for patients with atrial fibrillation without prior TIA or stroke is outlined in Table 3. Warfarin is also indicated as primary stroke prevention for patients with prosthetic heart valves and for recent acute myocardial infarction ( $<3$ months) with apical hypokinesis or thrombus and as secondary prevention in the presence of antiphospholipid antibody. It may also be indicated for recurrent cryptogenic stroke with PFO.

\section{Antihypertensive medications}

Observational studies demonstrate the strong positive association of stroke risk with rising blood pressure in patients with or without previous cerebrovascular events. ${ }^{63}$ Each 7.5-mm Hg rise in diastolic blood pressure doubles the risk of stroke ${ }^{64}$ while isolated systolic hypertension confers an even greater risk, especially among middle-aged men, who have an almost 5-fold risk of stroke. ${ }^{65} \mathrm{~A}$ metaanalysis of some of the largest primary prevention trials of thiazides and $\beta$-blockers, totalling nearly 50000 patients, demonstrated a $38 \%$ relative risk reduction in the rates of primary stroke with a difference of $5-6 \mathrm{~mm} \mathrm{Hg}$ in diastolic blood pressure over 5 years. ${ }^{66}$ Numerous guidelines have been developed for the treatment of hypertension ${ }^{67-70}$ that emphasize a target blood pressure of less than 140/90 mm
$\mathrm{Hg}$ and less than 130/85 $\mathrm{mm} \mathrm{Hg}$ for patients who have had a previous cerebrovascular event and have diabetes or other vascular disease.

The question of which antihypertensive medication should be the first choice remains controversial. Thiazide diuretics, angiotensin-converting-enzyme (ACE) inhibitors, angiotensin receptor blockers and $\beta$-blockers have all been studied (Table 4). Although thiazides and ACE inhibitors are both widely accepted as first-line therapy, choosing one over the other remains a contentious issue. While some studies have favoured thiazides ${ }^{71}$ and others ACE inhibitors, ${ }^{73,74}$ others have found no difference ${ }^{72}$ (Table 4). Practically, many patients require more than 1 antihypertensive to achieve normal blood pressure, which makes the need to choose one over the other irrelevant. Indeed, in one study the combination of ACE inhibitors and the diuretic indapamide was shown to be more effective than monotherapy for secondary stroke prevention. ${ }^{77}$ The LIFE study $^{75}$ (Table 4) suggests a role for angiotensin-receptor blockers (ARBs) in primary stroke prevention, demonstrating a $25 \%$ reduction in stroke for losartan when compared with atenolol. A substudy ${ }^{76}$ of patients with left ventricular hypertrophy and isolated systolic hypertension demonstrated an even more impressive $40 \%$ stroke reduction.

Although restoration of normal blood pressure remains central to preventing strokes, studies of ACE inhibitors or angiotensin-receptor blockers have demonstrated reductions in rates of stroke with very modest reductions in blood pressure..$^{74,78}$ Angiotensin-II is known to increase VCAM-1 expression and the production of inflammatory cytokines that promote atherogenesis ${ }^{79,80}$ (Fig. 1). Therefore, inhibition of angiotensin-II may have protective effects beyond blood pressure control.

\section{Summary}

Treatment of hypertension significantly reduces the risk of stroke. Both thiazides and ACE inhibitors have been shown to reduce this risk. Although there is controversy in the choice of the first-line medication, many patients require a combination of 2 or more antihypertensive drugs to

Table 3: Treatment of atrial fibrillation in primary stroke prevention*

\begin{tabular}{ll}
\hline Age & \multicolumn{1}{c}{ Treatment } \\
\hline$<\mathbf{6 5} \mathbf{y r}$ & \\
$\begin{array}{l}\text { No risk factors } \\
1 \text { or more risk factors } \dagger\end{array}$ & ASA \\
$\mathbf{6 5 - 7 5} \mathbf{~} \mathbf{r}$ & Warfarin (INR 2-3) \\
$\begin{array}{l}\text { No risk factors } \\
1 \text { or more risk factors } \dagger\end{array}$ & ASA or warfarin (INR 2-3) \\
$>\mathbf{7 5}$ yr & Warfarin (INR 2-3) \\
\hline *Adapted, with permission, from Laupacis et al. ${ }^{62}$ \\
$\begin{array}{l}+ \text { Risk factors include prior transient ischemic attack, systemic embolus or } \\
\text { stroke, hypertension, left ventricular dysfunction, diabetes mellitus and } \\
\text { coronary artery disease. }\end{array}$
\end{tabular}


normalize blood pressure. ${ }^{70}$ Therefore, thiazides, ACE inhibitors or a combination of both should all be considered as first-line therapy. Additional therapies should depend on the clinical circumstances. Patients intolerant of ACE inhibitors should be treated with an angiotensin-receptor blocker, particularly in the presence of diabetes or leftventricular hypertrophy for renal protective effects and cardiac afterload reduction respectively. $\beta$-Blockers may be preferred in the presence of diabetes, coronary artery disease or congestive heart failure. ${ }^{67}$

\section{Lipid-lowering agents}

LDL plays an important role in the formation of atherosclerotic plaques and the endothelial inflammatory pathway. Traditionally, the rationale of treating hyperlipidemia was to reduce the amount of substrate available for plaque for- mation. However, there is increasing evidence that agents used to treat hyperlipidemia, in particular the HMG-CoA reductase inhibitors (statins), also have anti-inflammatory and endothelial protective effects that are independent of lipid lowering and confer protection against vascular events. For example, statins have been shown to reduce levels of C-reactive protein, which results in a decreased risk of coronary events independent of lipid lowering. ${ }^{81,82}$

Unlike coronary artery disease, there is surprisingly little evidence to support a correlation between elevated serum cholesterol levels and overall cerebrovascular events. Prospective observational cohorts, with 450000 patients, demonstrated no correlation except among patients under the age of $45 .^{83}$ This may be in part because a positive association with nonhemorrhagic stroke is offset by an observed inverse relation with intracranial hemorrhage. ${ }^{84,85}$

Meta-analyses have shown that statins reduce the risk of

\section{Table 4: Major trials of antihypertensive drugs}

\begin{tabular}{|c|c|c|c|c|c|c|c|}
\hline Trial & Patients & Follow-up & Intervention & Absolute risk & OR $(95 \% \mathrm{Cl})$ & Superior & Comments \\
\hline $\begin{array}{l}\text { ALLHAT }^{71} \\
n=33357\end{array}$ & $\begin{array}{l}\text { HTN + } 1 \text { other } \\
\text { CAD risk } \\
\text { factor }\end{array}$ & $4.9 \mathrm{yr}$ & $\begin{array}{l}\text { Chlorthalidone } \\
\text { v. amlodipine } \\
\text { v. lisinopril }\end{array}$ & $\begin{array}{l}\text { Stroke, \% } \\
5.6 \\
5.4 \\
6.3\end{array}$ & $\begin{array}{c}\text { AM v. CT } \\
0.93(0.82-1.06) \\
\text { LS v. CT } \\
1.15(1.02-1.30)\end{array}$ & None & $\begin{array}{l}15 \% \text { greater risk of stroke } \\
\text { in LS group and } 40 \% \text { in } \\
\text { black population, but mean } \\
\text { BP also higher }\end{array}$ \\
\hline $\begin{array}{l}\text { STOP }-2^{72} \\
n=6614\end{array}$ & $\begin{array}{l}\text { Age } 70-84 \text { yr; } \\
\text { SBP } \geq 180 \\
\mathrm{~mm} \mathrm{Hg} \text { or } \\
\text { DBP } \geq 105 \\
\mathrm{~mm} \mathrm{Hg} \text { or } \\
\text { both }\end{array}$ & $5 \mathrm{yr}$ & $\begin{array}{c}\text { Conventional } \\
\text { v. ACE inhibitors } \\
\text { v. CCB }\end{array}$ & $\begin{array}{c}\text { Stroke per } \\
1000 \text { patient-yr } \\
22.2 \\
20.2 \\
19.5\end{array}$ & $\begin{array}{l}\text { ACE inhibitors v. } \\
\text { conventional } \\
0.90(0.74-1.08) \\
\text { CCB v. conventional } \\
0.88(0.73-1.06)\end{array}$ & None & $\begin{array}{l}\text { BP lowering similar in all } \\
\text { groups }(35 / 16-17 \mathrm{~mm} \mathrm{Hg}) \text {. } \\
\text { Conventional treatment } \\
\text { included } \beta \text {-blocker or } \\
\text { thiazides, or both }\end{array}$ \\
\hline $\begin{array}{l}\text { Second } \\
\text { Australian } \\
\text { National Blood } \\
\text { Pressure Study } \\
\text { Group }^{73} \\
n=6083\end{array}$ & $\begin{array}{l}\text { Age } 65-84 \text { yr; } \\
\text { SBP } \geq 160 \\
\mathrm{~mm} \mathrm{Hg} \text { or } \\
\text { DBP } \geq 90 \\
\mathrm{~mm} \mathrm{Hg}\end{array}$ & $4.1 \mathrm{yr}$ & $\begin{array}{l}\text { ACE inhibitors } \\
\text { v. thiazide }\end{array}$ & $\begin{array}{c}\text { Nonfatal stroke per } \\
1000 \text { patient-yr } \\
7.5 \\
7.8 \\
\text { Fatal stroke per } \\
1000 \text { patient-yr } \\
2.3 \\
1.2\end{array}$ & $\begin{array}{l}\text { HR } 0.93(0.70-1.26) \\
\text { HR } 1.91(1.04-3.50)\end{array}$ & $\begin{array}{l}\text { Possibly ACE } \\
\text { inhibitors }\end{array}$ & $\begin{array}{l}\text { BP lowering } 26 / 12 \mathrm{~mm} \mathrm{Hg} \\
\text { in both groups. Reduced } \\
\text { number of cardiovascular } \\
\text { events in ACE inhibitor } \\
\text { group, but increase in fatal } \\
\text { strokes }\end{array}$ \\
\hline $\begin{array}{l}\mathrm{HOPE}^{74} \\
n=9297\end{array}$ & $\begin{array}{l}\text { Vascular } \\
\text { disease or DM } \\
+ \text { additional } \\
\text { vascular risk } \\
\text { factor }\end{array}$ & $4.5 \mathrm{yr}$ & $\begin{array}{l}\text { ACE inhibitors } \\
\text { v. placebo }\end{array}$ & $\begin{array}{c}\text { Total stroke, \% } \\
3.4 \\
4.9\end{array}$ & $0.68(0.56-0.84)$ & $\begin{array}{c}\text { ACE } \\
\text { inhibitors }\end{array}$ & $\begin{array}{l}\text { BP lowering } 3.8 / 2.8 \mathrm{~mm} \mathrm{Hg} \\
\text { in ACE inhibitor group and } \\
0.7 / 1.1 \mathrm{~mm} \mathrm{Hg} \text { in placebo } \\
\text { group }\end{array}$ \\
\hline $\begin{array}{l}\text { LIFE }^{75} \\
n=9193\end{array}$ & $\begin{array}{l}\text { Age 55-80 yr; } \\
\text { SBP 160-200 } \\
\text { mm Hg + } \\
\text { DBP 95-115 } \\
\text { mm Hg + LVH }\end{array}$ & $4.8 \mathrm{yr}$ & $\begin{array}{l}\text { Losartan } \\
\text { v. atenolol }\end{array}$ & $\begin{array}{l}\text { Total stroke per } \\
1000 \text { patient-yr } \\
10.8 \\
14.5\end{array}$ & $0.75(0.63-0.89)$ & Losartan & $\begin{array}{l}\text { BP lowering similar in both } \\
\text { groups: } \\
\text { losartan } 30 / 17 \mathrm{~mm} \mathrm{Hg} \\
\text { atenolol } 29 / 17 \mathrm{~mm} \mathrm{Hg}\end{array}$ \\
\hline $\begin{array}{l}\text { LIFE substudy } \\
n=1326\end{array}$ & $\begin{array}{l}\text { As above } \\
\text { except } \\
\mathrm{DBP}<90 \\
\mathrm{~mm} \mathrm{Hg}\end{array}$ & $4.7 \mathrm{yr}$ & $\begin{array}{l}\text { Losartan } \\
\text { v. atenolol }\end{array}$ & $\begin{array}{l}\text { Total stroke per } \\
1000 \text { patient-yr } \\
10.6 \\
18.9\end{array}$ & $0.60(0.38-0.92)$ & Losartan & $\begin{array}{l}\text { BP lowering } 28 / 9 \mathrm{~mm} \mathrm{Hg} \\
\text { in both groups }\end{array}$ \\
\hline $\begin{array}{l}\text { PROGRESS }^{77} \\
n=6105\end{array}$ & $\begin{array}{l}\text { Stroke or TIA } \\
\text { in previous } \\
5 \mathrm{yr}\end{array}$ & $3.9 \mathrm{yr}$ & $\begin{array}{l}\text { ACE inhibitors } \\
\text { v. placebo } \\
\text { ACE inhibitors + } \\
\text { diuretic } \\
\text { v. double placebo }\end{array}$ & $\begin{array}{c}\text { Total stroke, \% } \\
12.3 \\
12.9\end{array}$ & $0.95(0.77-1.19)$ & $\begin{array}{l}\text { ACE inhibitors } \\
+ \text { diuretic }\end{array}$ & $\begin{array}{l}\text { BP lowering } 5 / 3 \mathrm{~mm} \mathrm{Hg} \\
\text { in ACE inhibitor group } \\
\text { and } 12 / 5 \mathrm{~mm} \mathrm{Hg} \text { in ACE } \\
\text { inhibitor + diuretic group }\end{array}$ \\
\hline
\end{tabular}

Note: When not provided in the study, unadjusted $\mathrm{ORs}$ and $95 \% \mathrm{Cls}$ were calculated. $\mathrm{HTN}=$ hypertension, $\mathrm{CAD}=$ coronary artery disease, $\mathrm{AM}=$ amlodipine, $\mathrm{CT}=$ chlorthalidone $\mathrm{LS}=$ lisinopril, $\mathrm{BP}=$ blood pressure, $\mathrm{SBP}=$ systolic blood pressure, $\mathrm{DBP}=$ diastolic blood pressure, $\mathrm{ACE}=$ angiotensin-converting enzyme, $\mathrm{CCB}=$ calcium-channel blocker. 
stroke. ${ }^{86-88}$ For primary prevention, an earlier study of pravastatin did not demonstrate a reduced risk of stroke among hyperlipidemic subjects. ${ }^{89}$ However, atorvastatin was recently shown to decrease the risk of stroke among patients not traditionally deemed hyperlipidemic (total cholesterol $<6.5 \mathrm{mmol} / \mathrm{L}$ ) but who had multiple vascular risk factors. ${ }^{90}$ Among patients who have had previous coronary artery disease, both simvastatin and pravastatin have been shown to decrease the risk of stroke without any increase in the risk of hemorrhagic stroke ${ }^{91,92}$ (Table 5). The Heart Protection Study (HPS) ${ }^{93}$ (Table 5) has now lowered the lipid treatment threshold even further in high-risk groups, demonstrating marked reductions in all vascular events with baseline $\mathrm{LDL}$ as low as $2.5 \mathrm{mmol} / \mathrm{L}$, irrespective of age, sex and other treatments.

Patients with low or normal LDL $(<3.6 \mathrm{mmol} / \mathrm{L})$, low high-density lipoprotein (HDL) levels $(<0.81 \mathrm{mmol} / \mathrm{L})$ and coronary artery disease may also benefit from gemfibrozil, a fibrate drug, which has been shown to reduce the risk of stroke by $31 \%{ }^{94}$ (Table 5). However, the safety and efficacy of gemfibrozil in combination with statins are unclear.

A meta-analysis of nonstatin interventions showed that a treatment strategy to reduce total cholesterol below $6 \mathrm{mmol} / \mathrm{L}$ with fibrate drugs, niacin and diet reduced the risk of stroke. ${ }^{88}$

\section{Summary}

All patients with prior TIA, ischemic stroke or with high risk factors for vascular disease as defined by HPS criteria should be treated with a statin irrespective of their serum cholesterol level. Fibrate drugs may also reduce the risk of stroke; however, the safety and efficacy of the combination of the fibrate and statin drugs are not clear.

\section{Carotid endarterectomy}

Carotid endarterectomy of a symptomatic severe stenosis of an internal carotid artery remains one of the most effective methods of preventing recurrent stroke, reducing the risk by up to two thirds ${ }^{95,96}$ (Table 6). The number-neededto-treat (NNT) to prevent 1 stroke at 2 years is 8 for high grade stenosis $(\geq 70 \%)$ and 20 for moderate stenosis $(50 \%-69 \%) .{ }^{99}$

Endarterectomy for asymptomatic stenosis of the internal carotid artery remains controversial. Although one study demonstrated a $53 \%$ relative risk reduction in ipsilateral stroke and death over 5 years, the number of events was small, with a higher NNT and men appeared to benefit considerably more than women. .7,99 $^{97}$ Long-term benefits may also be outweighed by the early risks of excess perioperative stroke or death (relative risk [RR] 6.52, 95\% CI 2.66-15.96) and are influenced by the complication rates of individual surgeons. ${ }^{100}$ Guidelines suggest that surgery should be considered only for asymptomatic carotid disease if the complication rate is less than $3 \%$ and the stenosis is greater than $60 \% .{ }^{101}$ The age and health of the patient, plaque stability and presence of coexisting cerebral artery disease should also be considered.

\begin{tabular}{|c|c|c|c|c|c|c|c|}
\hline Trial & Patients & Follow-up & Intervention & Absolute risks & OR $(95 \% \mathrm{Cl})$ & Superior & Comments \\
\hline $\begin{array}{l}\text { WOSCOPS }^{89} \\
n=6595\end{array}$ & $\begin{array}{l}\text { Men aged } 45-64 \mathrm{yr} \text {, } \\
\mathrm{TC} \geq 6.5 \mathrm{mmol} / \mathrm{L} \text {, } \\
\text { no history of } \mathrm{Ml}\end{array}$ & $4.9 \mathrm{yr}$ & $\begin{array}{l}\text { Pravastatin } \\
\text { v. placebo }\end{array}$ & $\begin{array}{c}\text { Stroke, \% } \\
1.4 \\
1.5\end{array}$ & - & None & $\begin{array}{l}\text { In pravastatin group, } \\
\text { TC decreased } 20 \% \text {, } \\
\text { LDL decreased } 26 \%\end{array}$ \\
\hline $\begin{array}{l}\text { ASCOT-LLA }^{90} \\
n=10305\end{array}$ & $\begin{array}{l}\mathrm{HTN}+\geq 3 \text { other } \\
\text { vascular risk factors, } \\
\mathrm{TC} \leq 6.5 \mathrm{mmol} / \mathrm{L}\end{array}$ & $3.3 \mathrm{yr}$ & $\begin{array}{l}\text { Atorvastatin } \\
\text { v. placebo }\end{array}$ & $\begin{array}{c}\text { Total stroke per } \\
1000 \text { patient-yr } \\
5.4 \\
7.4\end{array}$ & HR $0.73(0.56-0.96)$ & Atorvastatin & $\begin{array}{l}\text { In atorvastatin group, } \\
\text { TC decreased } 19 \% \text {, } \\
\text { LDL decreased } 29 \%\end{array}$ \\
\hline $\begin{array}{l}4-S^{91} \\
n=4444\end{array}$ & $\begin{array}{l}\text { CAD + } \\
\text { TC } 5.5-8.0 \mathrm{mmol} / \mathrm{L}\end{array}$ & $5.4 \mathrm{yr}$ & $\begin{array}{l}\text { Simvastatin } \\
\text { v. placebo }\end{array}$ & $\begin{array}{c}\text { Stroke rate, } \% \\
2.7 \\
4.3\end{array}$ & $0.63(0.46-0.88)$ & Simvastatin & $\begin{array}{l}\text { In simvastatin group, } \\
\text { TC decreased 25\%, } \\
\text { LDL decreased } 35 \%\end{array}$ \\
\hline $\begin{array}{l}\text { PPP CARE + } \\
\text { LIPID trials } \\
\text { combined }^{92} \\
n=6593\end{array}$ & $\begin{array}{l}\text { CAD + "average" } \\
\text { lipid levels; } \\
\text { mean TC: } \\
\text { CARE } 5.4 \mathrm{mmol} / \mathrm{L} \\
\text { LIPID } 5.7 \mathrm{mmol} / \mathrm{L}\end{array}$ & $\begin{array}{l}\text { CARE } 4.8 \mathrm{yr} \\
\text { LIPID } 6.1 \mathrm{yr}\end{array}$ & $\begin{array}{l}\text { Pravastatin } \\
\text { v. placebo }\end{array}$ & $\begin{array}{c}\text { Strokes per } \\
1000 \text { patient-yr } \\
6.2 \\
7.9\end{array}$ & HR 0.78 (0.65-0.93) & Pravastatin & - \\
\hline $\begin{array}{l}\mathrm{HPS}^{93} \\
n=20536\end{array}$ & $\begin{array}{l}\text { History of } \\
\text { vascular disease } \\
\text { or DM }\end{array}$ & $5 \mathrm{yr}$ & $\begin{array}{l}\text { Simvastatin } \\
\text { v. placebo }\end{array}$ & $\begin{array}{c}\text { All stroke, \% } \\
4.3 \\
5.7\end{array}$ & $0.75(0.66-0.85)$ & Simvastatin & $\begin{array}{l}\text { Benefits irrespective of } \\
\text { initial cholesterol levels }\end{array}$ \\
\hline $\begin{array}{l}\text { VA-HIT } \\
n=2531\end{array}$ & $\begin{array}{l}\mathrm{CAD} \\
\mathrm{HDL}<1.03 \mathrm{mmol} / \mathrm{L} \\
\mathrm{LDL}<3.6 \mathrm{mmol} / \mathrm{L} \\
\text { Trig }<3.39 \mathrm{mmol} / \mathrm{L}\end{array}$ & $5.1 \mathrm{yr}$ & $\begin{array}{l}\text { Gemfibrozil } \\
\text { v. placebo }\end{array}$ & $\begin{array}{c}\text { Total stroke, \% } \\
4.6 \\
6.0\end{array}$ & $\begin{array}{c}\text { Unadjusted OR } \\
0.76(0.53-1.07) \\
\text { Adjusted RRR } 31 \% \\
(2 \%-52 \%)\end{array}$ & Gemfibrozil & $\begin{array}{l}\text { In gemfibrozil group, } \\
\text { HDL increased } 6 \% \text {, } \\
\text { TC decreased } 4 \% \text {, } \\
\text { Trig decreased } 31 \%\end{array}$ \\
\hline
\end{tabular}

Note: When not provided in the study, unadjusted ORs and 95\% Cls were calculated. TC = total cholesterol, LDL = low-density lipoprotein, $\mathrm{HTN}=$ hypertension, $\mathrm{HDL}=$ high-density lipoprotein, Trig = triglycerides, $R R R=$ relative risk reduction. 


\section{Summary}

Carotid endarterectomy remains the definitive treatment in patients with symptomatic stenosis of the internal carotid artery of $70 \%$ or higher and in selected patients with a stenosis of $50 \%-69 \%$. We do not currently recommend surgery for asymptomatic disease, preferring to treat proven vascular risk factors aggressively with immediate follow-up in the event of any stroke symptoms.

\section{Conclusion}

We have presented the current understanding of the pathophysiology of atherosclerosis, the most important cause of stroke and the evidence available for the medical and surgical interventions for the prevention of stroke. Based on the evidence, it is clear that the use of an antiplatelet agent or warfarin and the correction of hypertension and hyperlipidemia all reduce the risk of stroke. In patients with symptomatic and severe internal carotid stenosis, it is also clear that carotid endarterectomy is the treatment of choice for stroke prevention.

The research in stroke prevention is ongoing with the evaluation of new drugs, refinement of knowledge of current medications and the tailoring of treatments for appropriate patient groups. Although beyond the scope of this review, the modification of lifestyle factors such as smoking and obesity remain crucial components to the prevention of stroke. Stroke risk may be reduced by almost $50 \%$ with regular exercise alone. ${ }^{102}$

The management of risk factors after stroke in general is not optimal ${ }^{103}$ and requires an increase in both the awareness of these risk factors and the appropriate, evidence-based use of existing therapeutic interventions. We have attempted to present the findings of important clinical trials to ascertain these risks and potential benefits, and we believe there is a need for more aggressive monitoring and treatment by both primary care physicians and specialists alike.

This article has been peer reviewed.

From the Stroke Prevention Clinic, University of Alberta Hospital, Mackenzie Health Sciences Centre (O'Rourke, Akhtar, Shuaib), and the Department of Medicine, Royal Alexandra Hospital (Dean), Edmonton, Alta.

Competing interests: None declared for Fintan O'Rourke and Naveed Akhtar Ashfaq Shuaib has received speaker fees and travel assistance from Sanofi-Synthelabo, Boehringer Ingelheim, Roche and Pfizer. Naeem Dean has received speaker fees from Sanofi-Synthelabo and Servier.

Contributors: Fintan O'Rourke, as the main author, was responsible for the writing, conception, intellectual content and design of the manuscript. Naeem Dean, Naveed Akhtar and Ashfaq Shuaib contributed to the intellectual content and design of the manuscript. All authors critically reviewed and approved the final version of the manuscript.

\section{References}

1. Selected leading causes of death by sex. Ottawa: Statistics Canada; 1997.

2. Hodgson C. Prevalence and disabilities of community-living seniors who report the effects of stroke. CMA7 1998;159(6 Suppl):9S-14S.

3. American Heart Association. 2002 heart and stroke statistical update. Dallas: The Association; 2001.

4. Moore R, Mao Y, Zhang J, Clarke K. Economic burden of illness in Canada, 1993. Ottawa: Health Canada; 1997. Cat no H21-136/1993E.

5. Johnston SC, Gress DR, Browner WS, Sidney S. Short-term prognosis after emergency department diagnosis of TIA. FAMA 2000;284(22):2901-6.

6. Hankey GJ, Jamrozik K, Broadhurst RJ, Forbes S, Burvill PW, Anderson CS, et al. Long-term risk of first recurrent stroke in the Perth Community Stroke Study. Stroke 1998;29(12):2491-500.

7. Petty GW, Brown RD Jr, Whisnant JP, Sicks JD, O'Fallon WM, Wiebers DO. Ischemic stroke subtypes: a population-based study of functional out-

\section{Table 6: Major trials of carotid endarterectomy}

\begin{tabular}{|c|c|c|c|c|c|c|c|}
\hline Trial & Patients & Follow-up & Intervention & Absolute risk, \% & OR $(95 \% \mathrm{Cl})$ & Superior & Comments \\
\hline $\begin{array}{l}\text { NASCET }^{95} \\
n=649\end{array}$ & $\begin{array}{l}70 \%-99 \% \\
\text { symptomatic } \\
\text { carotid stenosis }\end{array}$ & $18 \mathrm{mo}$ & $\begin{array}{c}\text { CEA } \\
\text { v. medical care }\end{array}$ & $\begin{array}{l}\text { Stroke or death } \\
\begin{array}{c}15.8 \\
32.3\end{array}\end{array}$ & $0.50(0.33-0.77)$ & CEA & $\begin{array}{l}\text { Clear early benefits for } \\
\text { CEA in severe symptomatic } \\
\text { carotid disease }\end{array}$ \\
\hline $\begin{array}{l}\text { NASCET }^{95} \\
n=858\end{array}$ & $\begin{array}{l}50 \%-69 \% \\
\text { symptomatic } \\
\text { carotid stenosis }\end{array}$ & $5 \mathrm{yr}$ & $\begin{array}{c}\text { CEA } \\
\text { v. medical care }\end{array}$ & $\begin{array}{l}\text { Stroke or death } \\
33.2 \\
43.3\end{array}$ & $0.67(0.51-0.90)$ & CEA & $\begin{array}{l}\text { Benefits obtained largely in } \\
\text { first } 2-3 \text { yr after CEA; } \\
\text { no benefits from CEA with } \\
\text { stenosis }<50 \%\end{array}$ \\
\hline $\begin{array}{l}\mathrm{ECST}^{96} \\
n=3024\end{array}$ & $\begin{array}{l}\text { TIA or } \\
\text { nondisabling } \\
\text { stroke in previous } \\
6 \text { mo related to } \\
\text { carotid stenosis }\end{array}$ & $\begin{array}{l}\text { CEA } 3 \mathrm{yr} ; \\
\text { Medical care } \\
3.2 \mathrm{yr}\end{array}$ & $\begin{array}{l}\text { CEA } \\
\text { v. medical care }\end{array}$ & $\begin{array}{l}\text { Stroke or death at } 3 \mathrm{yr} \\
\text { for } \geq 80 \% \text { ICA stenosis } \\
14.9 \\
26.5\end{array}$ & $\begin{array}{c}\text { HR } 0.78 \\
\text { (Cl not provided) } \\
p=0.01\end{array}$ & CEA & $\begin{array}{l}80 \% \text { stenosis on ECST } \\
\text { criteria is equal to } 70 \% \\
\text { stenosis on NASCET criteria }\end{array}$ \\
\hline $\begin{array}{l}\operatorname{ACAS}^{97} \\
n=1662\end{array}$ & $\begin{array}{l}\text { Asymptomatic } \\
\text { carotid stenosis } \\
\geq 60 \%\end{array}$ & $2.7 \mathrm{yr}$ & $\begin{array}{c}\text { CEA } \\
\text { v. medical care }\end{array}$ & $\begin{array}{c}\text { Ipsilateral stroke and } \\
\text { perioperative stroke } \\
\text { or death } \\
5.1 \\
11.0\end{array}$ & $0.63(0.40-0.98)$ & CEA & $\begin{array}{l}\text { CEA for asymptomatic } \\
\text { carotid disease remains } \\
\text { controversial }\end{array}$ \\
\hline $\begin{array}{l}\text { CAVATAS }^{98} \\
n=504\end{array}$ & $\begin{array}{l}\text { Carotid stenosis } \\
\text { suitable for CEA } \\
\text { or endovascular } \\
\text { treatment }\end{array}$ & $\begin{array}{l}\text { CEA } 1.98 \mathrm{yr} ; \\
\text { Endovascular } \\
1.95 \mathrm{yr}\end{array}$ & $\begin{array}{l}\text { Endovascular } \\
\text { treatment } \\
\text { v. CEA }\end{array}$ & $\begin{array}{c}\text { Death or } \\
\text { disabling stroke } \\
14.3 \\
14.2\end{array}$ & $1.03(0.64-1.64)$ & None & $\begin{array}{l}\text { Higher rates of procedural } \\
\text { stroke than those reported } \\
\text { in other major trials for } \\
\text { CEA }\end{array}$ \\
\hline
\end{tabular}

Note: When not provided in the study, unadjusted ORs and 95\% Cls were calculated. CEA = carotid endarterectomy, ICA = internal carotid artery. 
come, survival, and recurrence. Stroke 2000;31(5):1062-8.

8. Libby P, Ridker PM, Maseri A. Inflammation and atherosclerosis. Circulation 2002;105(9):1135-43.

9. Li H, Cybulsky MI, Gimbrone MA Jr, Libby P. An atherogenic diet rapidly induces VCAM-1, a cytokine-regulatable mononuclear leukocyte adhesion molecule, in rabbit aortic endothelium. Arterioscler Thromb 1993;13(2):197-204.

10. Gu L, Okada Y, Clinton SK, Gerard C, Sukhova GK, Libby P, et al. Absence of monocyte chemoattractant protein-1 reduces atherosclerosis in low density lipoprotein receptor-deficient mice. Mol Cell 1998;2(2):275-81.

11. Hansson G, Libby P. The role of the lymphocyte. In: Fuster V, Ross R, Topol E, editors. Atherosclerosis and coronary artery disease. New York: Lippincott-Raven; 1996. p. 557-68.

12. Topper JN, Cai J, Falb D, Gimbrone MA Jr. Identification of vascular endothelial genes differentially responsive to fluid mechanical stimuli: cyclooxygenase-2, manganese superoxide dismutase, and endothelial cell nitric oxide synthase are selectively up-regulated by steady laminar shear stress. Proc Natl Acad Sci U S A 1996;93(19):10417-22.

13. De Caterina R, Libby P, Peng HB, Thannickal VJ, Rajavashisth TB, Gimbrone MA Jr, et al. Nitric oxide decreases cytokine-induced endothelial activation. Nitric oxide selectively reduces endothelial expression of adhesion molecules and proinflammatory cytokines. 7 Clin Invest 1995;96(1):60-8.

14. Lee RT, Yamamoto C, Feng Y, Potter-Perigo S, Briggs WH, Landschulz $\mathrm{KT}$, et al. Mechanical strain induces specific changes in the synthesis and organization of proteoglycans by vascular smooth muscle cells. 7 Biol Chem 2001;276(17):13847-51

15. Libby P. Current concepts of the pathogenesis of the acute coronary syndromes. Circulation 2001;104(3):365-72.

16. Libby P, Simon DI. Inflammation and thrombosis: the clot thickens. Circulation 2001;103(13):1718-20.

17. Woollard KJ, Phillips DC, Griffiths HR. Direct modulatory effect of C-reactive protein on primary human monocyte adhesion to human endothelial cells. Clin Exp Immunol 2002;130(2):256-62.

18. Pasceri V, Willerson JT, Yeh ET. Direct proinflammatory effect of C-reactive protein on human endothelial cells. Circulation 2000;102(18):2165-8

19. Zwaka TP, Hombach V, Torzewski J. C-reactive protein-mediated low density lipoprotein uptake by macrophages: implications for atherosclerosis. Circulation 2001;103(9):1194-7.

20. Saito M, Ishimitsu T, Minami J, Ono H, Ohrui M, Matsuoka H. Relations of plasma high-sensitivity C-reactive protein to traditional cardiovascular risk factors. Atherosclerosis 2003;167(1):73-9.

21. Rost NS, Wolf PA, Kase CS, Kelly-Hayes M, Silbershatz H, Massaro JM, et al. Plasma concentration of C-reactive protein and risk of ischemic stroke and transient ischemic attack: the Framingham study. Stroke 2001;32(11):2575-9.

22. Ridker PM, Cushman M, Stampfer MJ, Tracy RP, Hennekens CH. Inflammation, aspirin, and the risk of cardiovascular disease in apparently healthy men. NEngl 7 Med 1997;336(14):973-9.

23. Hart RG, Halperin JL, McBride R, Benavente O, Man-Son-Hing M, Kronmal RA. Aspirin for the primary prevention of stroke and other major vascular events: meta-analysis and hypotheses. Arch Neurol 2000;57(3):326-32.

24. Sanmuganathan PS, Ghahramani P, Jackson PR, Wallis EJ, Ramsay LE. Aspirin for primary prevention of coronary heart disease: safety and absolute benefit related to coronary risk derived from meta-analysis of randomized trials. Heart 2001;85(3):265-71.

25. Collaborative meta-analysis of randomised trials of antiplatelet therapy for prevention of death, myocardial infarction, and stroke in high risk patients. Antithrombotic Trialists' Collaboration. BM7 2002;324(7329):71-86.

26. Diener HC, Cunha L, Forbes C, Sivenius J, Smets P, Lowenthal A. European Stroke Prevention Study. 2. Dipyridamole and acetylsalicylic acid in the secondary prevention of stroke. 7 Neurol Sci 1996;143(1-2):1-13.

27. A randomized, blinded, trial of clopidogrel versus aspirin in patients at risk of ischemic events (CAPRIE). CAPRIE Steering Committee. Lancet 1996;348 (9038):1329-39

28. Harbison JW. Ticlopidine versus aspirin for the prevention of recurrent stroke. Analysis of patients with minor stroke from the Ticlopidine Aspirin Stroke Study. Stroke 1992;23(12):1723-7.

29. Collaborative overview of randomized trials of antiplatelet therapy. I: Prevention of death, myocardial infarction, and stroke by prolonged antiplatelet therapy in various categories of patients. Antiplatelet Trialists' Collaboration. BM7 1994;308(6921):81-106.

30. Johnson ES, Lanes SF, Wentworth CE III, Satterfield MH, Abebe BL, Dicker LW. A metaregression analysis of the dose-response effect of aspirin on stroke. Arch Intern Med 1999;159(11):1248-53

31. Gibbons RJ, Abrams J, Chatterjee K, Daley J, Deedwania PC, Douglas JS, et al. ACC/AHA 2002 guideline update for the management of patients with chronic stable angina - summary article: a report of the American College of Cardiology/American Heart Association Task Force on Practice Guidelines (Committee on the Management of Patients with Chronic Stable Angina). Circulation 2003;107(1):149-58.

32. Tsuya T, Okada M, Horie H, Ishikawa K. Effect of dipyridamole at the usual oral dose on exercise-induced myocardial ischemia in stable angina pectoris. Am 7 Cardiol 1990;66(3):275-8.
33. Diener HC, Darius H, Bertrand-Hardy JM, Humphreys M; European Stroke Prevention Study 2. Cardiac safety in the European Stroke Prevention Study 2 (ESPS2). Int 7 Clin Pract 2001;55(3):162-3.

34. Yusuf S, Zhao F, Mehta SR, Chrolavicius S, Tognoni G, Fox KK, and the Clopidogrel in Unstable Angina to Prevent Recurrent Events Trial Investigators. Effects of clopidogrel in addition to aspirin in patients with acute coronary syndromes without ST-segment elevation [published errata in $N$ Engl $\mathcal{F}$ Med 2001;345:1506, 1716]. N Engl 7 Med 2001;345:494-502.

35. International Stroke Trial (IST): a randomized trial of aspirin, subcutaneous heparin, both, or neither among 19435 patients with acute ischemic stroke. International Stroke Trial Collaborative Group. Lancet 1997;349(9065):1569-81.

36. Saxena R, Lewis S, Berge E, Sandercock PA, Koudstaal PJ. Risk of early death and recurrent stroke and effect of heparin in 3169 patients with acute ischemic stroke and atrial fibrillation in the International Stroke Trial. Stroke 2001;32(10):2333-7.

37. Bath PM, Lindenstrom E, Boysen G, De Deyn P, Friis P, Leys D, et al. Tinzaparin in acute ischemic stroke (TAIST): a randomized aspirin controlled trial. Lancet 2001;358(9283):702-10.

38. Secondary prevention in non-rheumatic atrial fibrillation after transient ischemic attack or minor stroke. EAFT (European Atrial Fibrillation Trial) Study Group. Lancet 1993;342(8882):1255-62.

39. Adjusted-dose warfarin versus low-intensity, fixed-dose warfarin plus aspirin for high-risk patients with atrial fibrillation: Stroke Prevention in Atrial Fibrillation III randomized clinical trial. Lancet 1996;348(9028):633-8.

40. A randomized trial of anticoagulants versus aspirin after cerebral ischemia of presumed arterial origin. The Stroke Prevention in Reversible Ischemia Trial (SPIRIT) Study Group. Ann Neurol 1997;42(6):857-65.

41. Mohr JP, Thompson JL, Lazar RM, Levin B, Sacco RL, Furie KL, et al, for the Warfarin-Aspirin Recurrent Stroke Study Group. A comparison of warfarin and aspirin for the prevention of recurrent ischemic stroke. $N$ Engl $\mathcal{F}$ Med 2001;345(20):1444-51.

42. Risk factors for stroke and efficacy of antithrombotic therapy in atrial fibrillation. Analysis of pooled data from five randomized controlled trials. Arch Intern Med 1994;154(13):1449-57.

43. Hylek EM, Go AS, Chang Y, Jensvold NG, Henault LE, Selby JV, et al. Effect of intensity of oral anticoagulation on stroke severity and mortality in atrial fibrillation. $N$ Engl 7 Med 2003;349(11):1019-26.

44. Van Gelder IC, Hagens VE, Bosker HA, Kingma JH, Kamp O, Kingma T, et al; Rate Control versus Electrical Cardioversion for Persistent Atrial Fibrillation Study Group. A comparison of rate control and rhythm control in patients with recurrent persistent atrial fibrillation. NEngl 7 Med 2002;347(23):1834-40.

45. Wyse DG, Waldo AL, DiMarco JP, Domanski MJ, Rosenberg Y, Schron EB, et al; Atrial Fibrillation Follow-up Investigation of Rhythm Management (AFFIRM) Investigators. A comparison of rate control and rhythm control in patients with atrial fibrillation. N Engl 7 Med 2002;347(23):1825-33.

46. Stein PD, Alpert JS, Bussey HI, Dalen JE, Turpie AG. Antithrombotic therapy in patients with mechanical and biological prosthetic heart valves. Chest 2001;119(1 Suppl):220S-227S.

47. Johannessen KA, Nordrehaug JE, von der Lippe G. Left ventricular thrombosis and cerebrovascular accident in acute myocardial infarction. $\mathrm{Br}$ Heart 7 1984;51(5):553-6.

48. Vecchio C, Chiarella F, Lupi G, Bellotti P, Domenicucci S. Left ventricular thrombus in anterior acute myocardial infarction after thrombolysis. A GISSI-2 connected study. Circulation 1991;84(2):512-9.

49. Vaitkus PT, Barnathan ES. Embolic potential, prevention and management of mural thrombus complicating anterior myocardial infarction: a meta-analysis. 7 Am Coll Cardiol 1993;22(4):1004-9.

50. Cairns JA, Theroux P, Lewis HD Jr, Ezekowitz M, Meade TW. Antithrombotic agents in coronary artery disease. Chest 2001;119(1 Suppl):228S-252S.

51. Amarenco P, Cohen A, Tzourio C, Bertrand B, Hommel M, Besson G, et al. Atherosclerotic disease of the aortic arch and the risk of ischemic stroke. $N$ Engl 7 Med 1994;331(22):1474-9.

52. Cohen A, Tzourio C, Bertrand B, Chauvel C, Bousser MG, Amarenco P. Aortic plaque morphology and vascular events: a follow-up study in patients with ischemic stroke. FAPS Investigators. French Study of Aortic Plaques in Stroke. Circulation 1997;96(11):3838-41.

53. Ferrari E, Vidal R, Chevallier T, Baudouy M. Atherosclerosis of the thoracic aorta and aortic debris as a marker of poor prognosis: benefit of oral anticoagulants. 7 Am Coll Cardiol 1999;33(5):1317-22.

54. Dressler FA, Craig WR, Castello R, Labovitz AJ. Mobile aortic atheroma and systemic emboli: efficacy of anticoagulation and influence of plaque morphology on recurrent stroke. 7 Am Coll Cardiol 1998;31(1):134-8.

55. Windecker S, Meier B. Patent foramen ovale and atrial septal aneurysm: when and how should they be treated. ACC Curr 7 Rev 2002;11:97-101.

56. Orgera MA, O'Malley PG, Taylor AJ. Secondary prevention of cerebral ischemia in patent foramen ovale: systematic review and meta-analysis. Soutb Med 7 2001;94(7):699-703.

57. Onorato E, Melzi G, Casilli F, Pedon L, Rigatelli G, Carrozza A, et al. Patent foramen ovale with paradoxical embolism: mid-term results of transcatheter closure in 256 patients. 7 Interv Cardiol 2003;16(1):43-50.

58. Homma S, Sacco RL, Di Tullio MR, Sciacca RR, Mohr JP. Atrial anatomy in 
non-cardioembolic stroke patients: effect of medical therapy.7 Am Coll Cardiol 2003;42(6):1066-72.

59. Anticardiolipin antibodies are an independent risk factor for first ischemic stroke. The Antiphospholipid Antibodies in Stroke Study (APASS) Group. Neurology 1993;43(10):2069-73.

60. Cuadrado MJ, Khamashta MA. The anti-phospholipid antibody syndrome (Hughes syndrome): therapeutic aspects. Baillieres Best Pract Res Clin Rbeumato 2000;14(1):151-63.

61. Khamashta MA, Cuadrado MJ, Mujic F, Taub NA, Hunt BJ, Hughes GR. The management of thrombosis in the antiphospholipid-antibody syndrome. N Engl 7 Med 1995;332(15):993-7.

62. Laupacis A, Albers G, Dalen J, Dunn MI, Jacobson AK, Singer DE. Antithrombotic therapy in atrial fibrillation. Chest 1998;114(5 Suppl):579S-89S.

63. Kannel WB, Wolf PA, Verter J, McNamara PM. Epidemiologic assessment of the role of blood pressure in stroke. The Framingham study. FAMA 1970; 214(2):301-10.

64. MacMahon S, Peto R, Cutler J, Collins R, Sorlie P, Neaton J, et al. Blood pressure, stroke, and coronary heart disease. Part 1, Prolonged differences in blood pressure: prospective observational studies corrected for the regression dilution bias. Lancet 1990;335(8692):765-74.

65. Petrovitch H, Curb JD, Bloom-Marcus E. Isolated systolic hypertension and risk of stroke in Japanese-American men. Stroke 1995;26(1):25-9.

66. Collins R, MacMahon S. Blood pressure, antihypertensive drug treatment and the risks of stroke and of coronary heart disease. Br Med Bull 1994;50 (2):272-98

67. McAlister FA, Zarnke KB, Campbell NR, Feldman RD, Levine M, Mahon J, et al, for Canadian Hypertension Recommendations Working Group. The 2001 Canadian recommendations for the management of hypertension: part two - therapy. Can 7 Cardiol 2002; 18:625-41.

68. 1999 World Health Organization-International Society of Hypertension guidelines for the management of hypertension. Guidelines Subcommittee. 7 Hypertens 1999;17(2):151-83.

69. Staessen JA, Wang J. Blood-pressure lowering for the secondary prevention of stroke. Lancet 2001;358(9287):1026-7.

70. Chobanian AV, Bakris GL, Black HR. The seventh report of the Joint National Committee on Prevention, Detection, Evaluation, and Treatment of High Blood Pressure: the JNC 7 report. FAMA 2003;289(19):2560-72.

71. Major outcomes in high-risk hypertensive patients randomized to angiotensin-converting enzyme inhibitor or calcium channel blocker vs diuretic: the Antihypertensive and Lipid-Lowering Treatment to Prevent Heart Attack Trial (ALLHAT). 7AMA 2002;288(23):2981-97.

72. Hansson L, Lindholm LH, Ekbom T, Dahlof B, Lanke J, Schersten B, et al. Randomized trial of old and new antihypertensive drugs in elderly patients: cardiovascular mortality and morbidity the Swedish Trial in Old Patients with Hypertension-2 study. Lancet 1999;354(9192):1751-6.

73. Wing LM, Reid CM, Ryan P, Beilin LJ, Brown MA, Jennings GL, et al. Second Australian National Blood Pressure Study Group. A comparison of outcomes with angiotensin-converting-enzyme inhibitors and diuretics for hypertension in the elderly. NEngl 7 Med 2003;348(7):583-92.

74. Bosch J, Yusuf S, Pogue J, Sleight P, Lonn E, Rangoonwala B, et al; HOPE Investigators. Heart outcomes prevention evaluation. Use of ramipril in preventing stroke: double blind randomized trial. BM7 2002;324(7339):699-702.

75. Dahlof B, Devereux RB, Kjeldsen SE. Cardiovascular morbidity and mortality in the Losartan Intervention for Endpoint reduction in hypertension study (LIFE): a randomised trial against atenolol. Lancet 2002;359(9311):995-1003.

76. Kjeldsen SE, Dahlof B, Devereux RB, Julius S, Aurup P, Edelman J, et al; LIFE (Losartan Intervention for Endpoint Reduction) Study Group. Effects of losartan on cardiovascular morbidity and mortality in patients with isolated systolic hypertension and left ventricular hypertrophy: a Losartan Intervention for Endpoint Reduction (LIFE) substudy. FAMA 2002;288(12):1491-8.

77. PROGRESS Collaborative Group. Randomized trial of a perindopril-based blood-pressure-lowering regimen among 6,105 individuals with previous stroke or transient ischemic attack. Lancet 2001;358(9287):1033-41.

78. Lithell H, Hansson L, Skoog I, Elmfeldt D, Hofman A, Olofsson B, et al; SCOPE Study Group. The Study on Cognition and Prognosis in the Elderly (SCOPE): principal results of a randomized double-blind intervention trial. $\mathcal{F}$ Hypertens 2003;21(5):875-86.

79. Kranzhofer R, Schmidt J, Pfeiffer CA, Hagl S, Libby P, Kubler W. Angiotensin induces inflammatory activation of human vascular smooth muscle cells. Arterioscler Thromb Vasc Biol 1999;19(7):1623-9.

80. Tummala PE, Chen XL, Sundell CL, Laursen JB, Hammes CP, Alexander $\mathrm{RW}$, et al. Angiotensin II induces vascular cell adhesion molecule-1 expression in rat vasculature: a potential link between the renin-angiotensin system and atherosclerosis. Circulation 1999;100(11):1223-9.

81. Ridker PM, Rifai N, Pfeffer MA, Sacks F, Braunwald E. Long-term effects of pravastatin on plasma concentration of C-reactive protein. The Cholestero and Recurrent Events (CARE) Investigators. Circulation 1999;100(3):230-5.
82. Ridker PM, Rifai N, Clearfield M, Downs JR, Weis SE, Miles JS, et al; Air Force/Texas Coronary Atherosclerosis Prevention Study Investigators. Measurement of C-reactive protein for the targeting of statin therapy in the primary prevention of acute coronary events. N Engl 7 Med 2001;344(26):1959-65.

83. Cholesterol, diastolic blood pressure, and stroke: 13,000 strokes in 450,000 people in 45 prospective cohorts. Prospective studies collaboration. Lancet 1995;346:1647-53.

84. Neaton JD, Blackburn H, Jacobs D, Kuller L, Lee DJ, Sherwin R, et al. Serum cholesterol level and mortality findings for men screened in the Multiple Risk Factor Intervention Trial. Multiple Risk Factor Intervention Trial Research Group. Arch Intern Med 1992;152(7):1490-500.

85. Blood pressure, cholesterol, and stroke in eastern Asia. Eastern Stroke and Coronary Heart Disease Collaborative Research Group. Lancet 1998;352 (9143):1801-7

86. Atkins D, Psaty BM, Koepsell TD, Longstreth WT Jr, Larson EB. Cholesterol reduction and the risk for stroke in men. A meta-analysis of randomized, controlled trials. Ann Intern Med 1993;119(2):136-45.

87. Di Mascio R, Marchioli R, Tognoni G. Cholesterol reduction and stroke occurrence: an overview of randomized clinical trials. Cerebrovasc Dis 2000;10(2) $85-92$.

88. Corvol JC, Bouzamondo A, Sirol M, Hulot JS, Sanchez P, Lechat P. Differential effects of lipid-lowering therapies on stroke prevention: a meta-analysis of randomized trials. Arch Intern Med 2003;163(6):669-76.

89. Shepherd J, Cobbe SM, Ford I, Isles CG, Lorimer AR, MacFarlane PW, et al. Prevention of coronary heart disease with pravastatin in men with hypercholesterolemia. West of Scotland Coronary Prevention Study Group. N Engl 7 Med 1995;333(20):1301-7.

90. Sever PS, Dahlof B, Poulter NR, Wedel H, Beevers G, Caulfield M, et al. Prevention of coronary and stroke events with atorvastatin in hypertensive patients who have average or lower-than-average cholesterol concentrations, in the Anglo-Scandinavian Cardiac Outcomes Trial - Lipid Lowering Arm (ASCOT-LLA): a multicentre randomized controlled trial. Lancet 2003;361 (9364):1149-58.

91. Randomized trial of cholesterol lowering in 4444 patients with coronary heart disease: the Scandinavian Simvastatin Survival Study (4S). Lancet 1994;344 (8934):1383-9.

92. Byington RP, Davis BR, Plehn JF, White HD, Baker J, Cobbe SM, et al. Reduction of stroke events with pravastatin: the Prospective Pravastatin Pooling (PPP) Project. Circulation 2001;103(3):387-92

93. Heart Protection Study Collaborative Group. MRC/BHF Heart Protection Study of cholesterol lowering with simvastatin in 20,536 high-risk individuals: a randomized placebo-controlled trial. Lancet 2002;360(9326):7-22.

94. Bloomfield Rubins H, Davenport J, Babikian V, Brass LM, Collins D, Wexler $\mathrm{L}$, et al; VA-HIT Study Group. Reduction in stroke with gemfibrozil in men with coronary heart disease and low HDL cholesterol: the Veterans Affairs HDL Intervention Trial (VA-HIT). Circulation 2001;103(23):2828-33.

95. Beneficial effect of carotid endarterectomy in symptomatic patients with high-grade carotid stenosis. North American Symptomatic Carotid Endarterectomy Trial Collaborators. N Engl 7 Med 1991;325(7):445-53.

96. Randomized trial of endarterectomy for recently symptomatic carotid stenosis: final results of the MRC European Carotid Surgery Trial (ECST). Lancet 1998;351(9113):1379-87.

97. Endarterectomy for asymptomatic carotid artery stenosis. Executive Committee for the Asymptomatic Carotid Atherosclerosis Study. JAMA 1995;273 (18):1421-8

98. Endovascular versus surgical treatment in patients with carotid stenosis in the Carotid and Vertebral Artery Transluminal Angioplasty Study (CAVATAS): a randomized trial. Lancet 2001;357(9270):1729-37.

99. Gorelick PB. Carotid endarterectomy: Where do we draw the line? Stroke 1999;30(9):1745-50

100. Chambers BR, You RX, Donnan GA. Carotid endarterectomy for asymptomatic carotid stenosis. Cochrane Database Syst Rev 2000;(2):CD001923.

101. Findlay JM, Tucker WS, Ferguson GG, Holness RO, Wallace MC, Wong $\mathrm{JH}$. Guidelines for the use of carotid endarterectomy: current recommendations from the Canadian Neurosurgical Society. CMA7 1997;157(6):653-9.

102. Hu FB, Stampfer MJ, Colditz GA, Ascherio A, Rexrode KM, Willett WC, et al. Physical activity and risk of stroke in women. 7AMA 2000;283(22):2961-7.

103. Mouradian MS, Majumdar SR, Senthilselvan A, Khan K, Shuaib A. How well are hypertension, hyperlipidemia, diabetes, and smoking managed after a stroke or transient ischemic attack? Stroke 2002;33(6):1656-9.

Correspondence to: Fintan O'Rourke, Dept. of Elderly Care Medicine, Barnet General Hospital, Wellhouse Lane, Barnet, UK EN5 3DJ 